\title{
Remote Sensing of Population and Coral Destruction for Long Term on Small Islands
}

\author{
Nurjannah Nurdinn ${ }^{1,3}$, Muhammad Hatta ${ }^{1}$, Supriadi Mashoreng ${ }^{1}$, Khairul Amri ${ }^{1}$, Dwia Aries Tina \\ Pulubuhu' ${ }^{2}$, Agus Aris ${ }^{3}$, and M. Akbar AS ${ }^{3}$, Teruhisa Komatsu ${ }^{4,5}$ \\ 1 Marine Science and Fisheries Faculty, Hasanuddin University, Makassar, 90245, Indonesia; \\ nurj_din@yahoo.com \\ 2 Social and Political Sciences Faculty, Hasanuddin University, Makassar, 90245, Indonesia; \\ dwiatn@yahoo.com \\ 3 Research and Development Center for Marine, Coast, and Small Island, Hasanuddin University, Jl. Perintis \\ Kemerdekaan km.10, Makassar, 90245, Indonesia; nurj_din@yahoo \\ 4 Atmosphere and Ocean Research Institute, The University of Tokyo, Kashiwa 277-8564, Japan \\ 5 Present affiliation: Yokohama College of Commerce, Yokohama 230-8577, Japan \\ * Correspondence: nurj_din@yahoo; Tel.: +62-8138-739-0203
}

Received: date; Accepted: date; Published: date

\begin{abstract}
In general, remote sensing has proven to be a powerful tool in the overall understanding of natural and anthropogenic phenomena. Satellites have become useful tools for tasks such as characterization, monitoring, and the continuous prospecting of natural resources. This research aims to analyze spatial dynamic and destructive on coral reefs area and correlation between live coral reduction and population on small islands. Landsat MSS, TM, ETM, and OLI-TIRS are used to spatial analyze of coral reef dynamics from 1972 to 2016. The image processing includes gap-filling, atmospheric correction, geometric correction, image composite (true color), water column correction, unsupervised classification, reclassification, accuracy assessment. The statistical analysis identifies the relationship between dynamic population data with a reduction of live coral, namely Principal Component Analysis (PCA) and Multiple Regression Analysis. The effect of the population shows a positive correlation with the reduction in the area of live coral, although it is significant. The fact is the practice of coral destruction on an island; it is usually not only caused or carried out by residents who live on the island but also carried out by other residents of different islands.
\end{abstract}

Keywords: coral reef; Landsat; population; remote sensing; small islands

\section{Introduction}

Utilization of remote sensing satellite technology in providing information on coral reefs spatially and temporally continues to progress until now. Shallow water mapping using sensing technology is far more cost and time-efficient with extensive area coverage in identifying coral reefs [1-2]. Satellite imagery can classify shallow water habitats based on spectral characteristics to map the spatial and temporal distribution of coral reef and seagrass ecosystems [3-10].

Indonesia, as a geographical sub-regional, has a coastline length of $95,181 \mathrm{~km}$, and It has a coral reef of approximately $50,000 \mathrm{~km}^{2}$ [11], and as a mega biodiversity state. Indonesia's coral reefs are famous for its biodiversity and ecological complexity. The global center of tropical marine biodiversity known as the Coral Triangle Initiative (CTI) covering six countries, namely Indonesia, Malaysia, the Philippines, Timor Leste, Papua New Guinea, and the Solomon Islands. The coastal region and the small islands of South Sulawesi, Indonesia is estimated to be one of the centers of destructive fishing activities (cyanide and bombs) in Indonesia, where the Spermonde Islands hold a very significant contribution to fishery activities in South Sulawesi, and is an area that is very vulnerable to fishing activities which damages the surrounding ecosystems including coral reefs. 
Coral reefs are one of the critical coastal ecosystems that can provide valuable environmental products and services for the lives of coastal communities. However, the existence of coral reefs currently faces a variety of threats, both from global climate change and human activities. The response of coral reefs to temperature increases is very sensitive; an increase in water temperature of $2^{\circ} \mathrm{C}$ can cause mass death of coral reefs [12]. According to [13], coral reefs damage mostly caused by global warming, natural disasters, and human activities, but human activity is the leading cause of coral reef damage.

In recent decades, coral reefs have significantly degraded due to not environmentally friendly fishing, pollution, coastal reclamation, global warming, hurricanes, and increased concentrations of greenhouse gases in the atmosphere [14]. Coral reefs are one of the most threatened marine ecosystems as a result of the disruption of natural changes, as well as from anthropogenic, both on a global and local scale [15].

The Spermonde Islands consist of 54 small islands, fourteen of them are no population islands, and 130 within the criteria of the gusung, which is sand dune and coral fragments and shells that accumulate to form like small islands and some will appear from above when high tide [16]. Monitoring techniques over a large area are carried out spatially by utilizing satellite imagery data. This approach has been widely carried out before, namely [4] has conducted a study related to habitat changes in coral reef ecosystems in the Red Sea, Hurghada, Egypt and for the first time on Bunaken Island, North Sulawesi, Indonesia has carried out detailed classification more than 150 habitat types using high-resolution ( $2 \mathrm{~m}$ ) image data, GeoEye-1 by [14]. All of these studies have provided excellent results for supporting the management of coral reef areas.

The purpose of this study is to map shallow waters by using multi-sensor satellite imagery over a long period and analyze the effect of increasing numbers of small island inhabitants on the Spermonde Islands on damage to coral reefs mathematically based on an indication that an increase in population, especially on small islands, raises concerns about the uncontrolled survival of coral reefs. Spatial information about coral reef conditions and dynamics at the right scale is a fundamental prerequisite in the understanding and management of shallow water ecosystems [17].

\section{Materials and Methods}

\subsection{Field Study}

The research area is several small islands located in the waters of the Spermonde Islands, South Sulawesi Province, Indonesia. The waters of the Spermonde Islands consist of small islands located in the Sulawesi Strait, and this strait is between Sulawesi Island and Kalimantan Island, as shown in Figure 1.

The survey location was decided to divide into two categories, namely small inhabited islands, and small uninhabited islands. Seventeen small inhabited islands were selected as representative locations: a) Ballang Caddi, b) Ballang Lompo, c) Bangkobangkoang, d) Kulambing, e) Karanrang, f) Laiya, g) Sabuton, h) Saugi, i) Satando, j) Bontosua, k) Badi, 1) Pajenekang, m) Podang-Podang Lompo, n) Samatellu Lompo, o) Salebo, p) Sarappo Keke, q) Sarappo Lompo island, and two uninhabited category, namely Kondingareng Keke and Samatellu Pedda island.

The study area is in waters of small islands, Spermonde archipelago, South Sulawesi Province. The waters of the Spermonde archipelago consist of small islands, as shown in Figure 1, located in the Sulawesi Strait, and it is between Sulawesi Island and Kalimantan Island. 


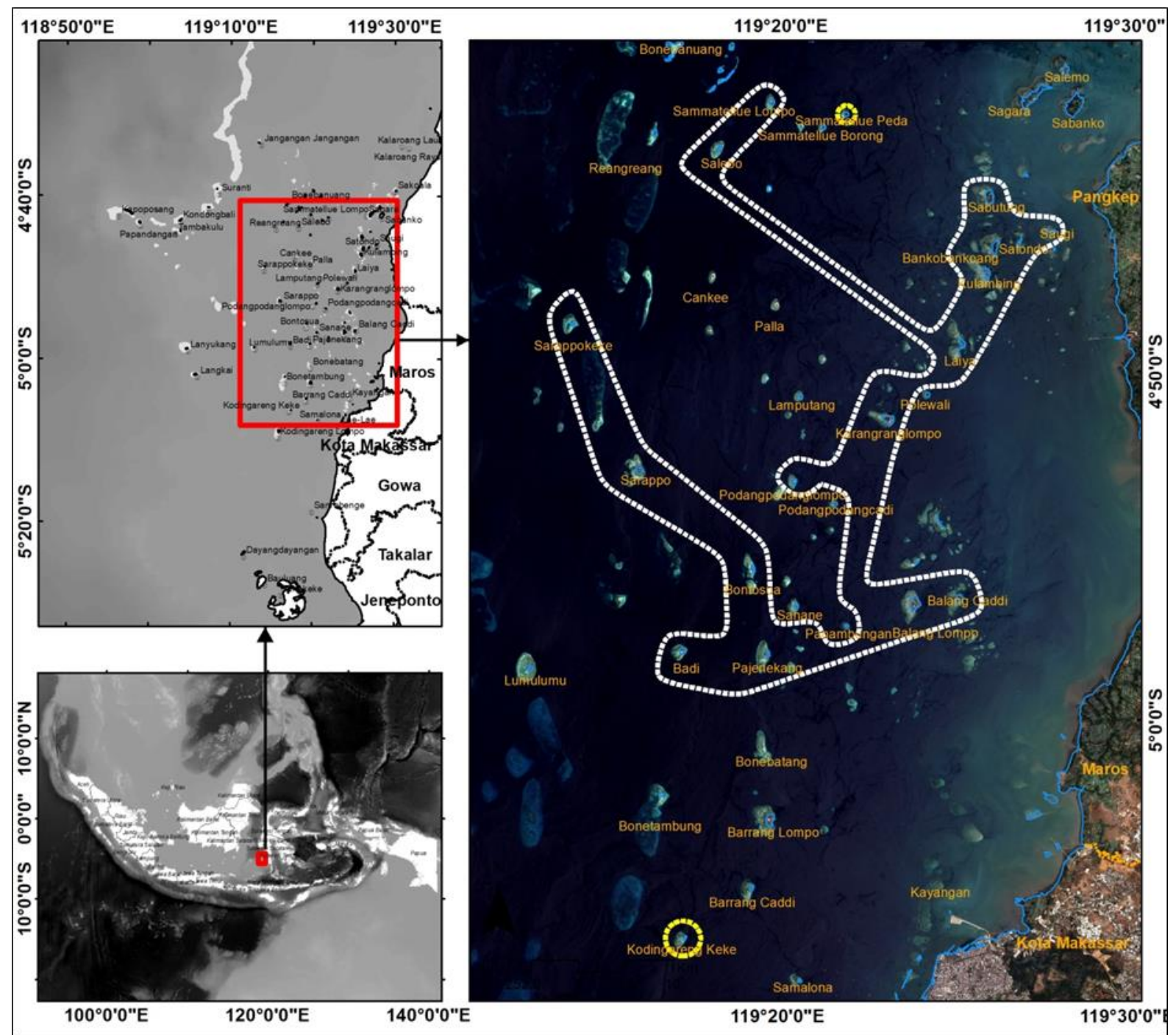

Figure 1. Field location is small islands in Spermonde island, South Sulawesi, Indonesia. Research location of Seventeen small populated islands as the uninhabited category are in the red circle, and nine small islands as inhabited in the purple line

\subsection{Data}

The spatial data used in this study to determine the distribution and condition of coral reefs in the Spermonde Islands is Landsat satellite imagery data with different sensor types. Data recording in 1972, 1978, 1984, 1990, 1996, 2002, 2006, and 2016 which was obtained freely from http://earthexplorer.usgs.gov/). This Landsat satellite image data has a spatial resolution of 60 and 30 meters. The UAV provides detailed images of the density of houses and data on the number of houses on small islands. Population data for 2006 to 2017 sourced from the Indonesian Central Statistics Agency [18].

\subsection{Image processing of coastal ecosystem}

Satellite image data processing is carried out to determine the distribution and condition of coral reefs. The processing consists of several stages, including the process of geometric and radiometric correction of satellite images, cropping, RGB composites, image pansharpening, depth invariant index, unsupervised classification, ground truth, accuracy assessment, and reclassify. The atmospheric correction process is done using a DOS (Dark Object Subtraction) module. The geometric correction technique used in this study is the transformation of the GCP (Ground Control Point). Geometric errors in the original image are corrected by rectification. Image rectification based on existing GCP position information aims to place the pixel image in actual position on the surface of 
the earth. Image cutting is an image processing used to minimize the observation of the study area. The masking process is carried out to limit the study area and eliminate the effects of land, deep water, and other objects that are not needed in the process of further image processing.

Some previous studies mapping the habitat of shallow waters and water column with remote sensing technology said that one of the influences of optical properties that characterize a watershed is attenuation [19-22]. Lyzenga algorithm is combining two channels of visible light. They are blue $(490 \mathrm{~nm})$ and green $(560 \mathrm{~nm})$ band. Two bands are visible light, and the algorithm is:

$$
K i / K i=a+\sqrt{a^{2}+1}
$$

Where:

$$
\begin{gathered}
a=\frac{\sigma i i-\sigma j j}{2 \sigma i j} \\
\sigma i j=\overline{X i X j}-\overline{X i X j}
\end{gathered}
$$

$\mathrm{Ki} / \mathrm{Kj}$, coefficient of attenuation, oij is the variance measurements of $\mathrm{X}_{\mathrm{i}}$, ojj is the variance measurements of $X_{j}$, and oij is $X_{i}$ and $X_{j}$ covariance. The next step is to calculate the depth invariant index (DII) with the algorithm:

$$
\mathrm{DII}=\log (\mathrm{xi})+[(\mathrm{Ki} / \mathrm{Kj}) * \log (\mathrm{xj})]
$$

Where:

$\mathrm{y}:$ Extraction of basic information

$\mathrm{i}$ : Blue band value

$\mathrm{j}$ : Green band value

$\mathrm{ki} / \mathrm{kj}$ : Attenuation coefficient

Determination of the point of observation is determined before carrying out a field survey using the unsupervised classification method. The unsupervised classification technique uses the ISODATA (iterative self-organizing data analysis technique) algorithm to group multispectral image pixels into relatively homogeneous groups. Isodata algorithm works by combining the same cluster and data in a cluster so that they can divide based on maximum standard deviations [23]. The parameters in the Isodata Algorithm are:

$K 0$ : number of initial clusters

nmin : Minimum cluster data

$\sigma 2 \max$ : Maximum variant (merge)

dmin : minimum (split) pair distance

Retrieval of data in the field aims to determine the type of the object at the study site that appears to have a different color and hue on the image. Field data is then used as a basis for determining the type of object cover when identifying objects and validating the results of the classification results. The image generated by the algorithm transformation is then reclassified. Classes that have almost the same spectral value made into one class or different classes, but having the same object are also merged into one class. Class merging is done after the field survey. Field survey data is used as a reference in conducting class merging.

The accuracy test uses a confusion matrix. The matrix compares habitat classes resulting from image classification against actual classes from the field survey results. Column data is the result of classification that represents the calculation of producer's accuracy (PA), while row data is the result of field observations by observers and is used in the calculation of the user's accuracy (UA). The more classification results that are aligned with the results of observations, the overall accuracy value will be higher. The expected accuracy value must meet the requirements more significant than $60 \%$ [20] so that the results of the percentage of OA values obtained can be used as proof of the accuracy of the image classification. The calculation of each accuracy is done by the following equation [24].

Kappa ' mathematical accuracy is: 


$$
K=\frac{N \sum_{i=1}^{r} X_{I I}-\sum_{i=1}^{r}\left(X_{i+*} X_{+i}\right)}{N^{2}-\sum_{i=1}^{r}\left(X_{i+} * X_{+i}\right)}
$$

Where:

$\mathrm{N}$ : the total number of cells in the matrix

$r$ : the number of rows in the matrix

$X i i$ : the number in row $\mathrm{i}$ and column $\mathrm{i}$

$x+1$ : the total observations for column $i$, and

$x 1+$ : the total observations in row $i$

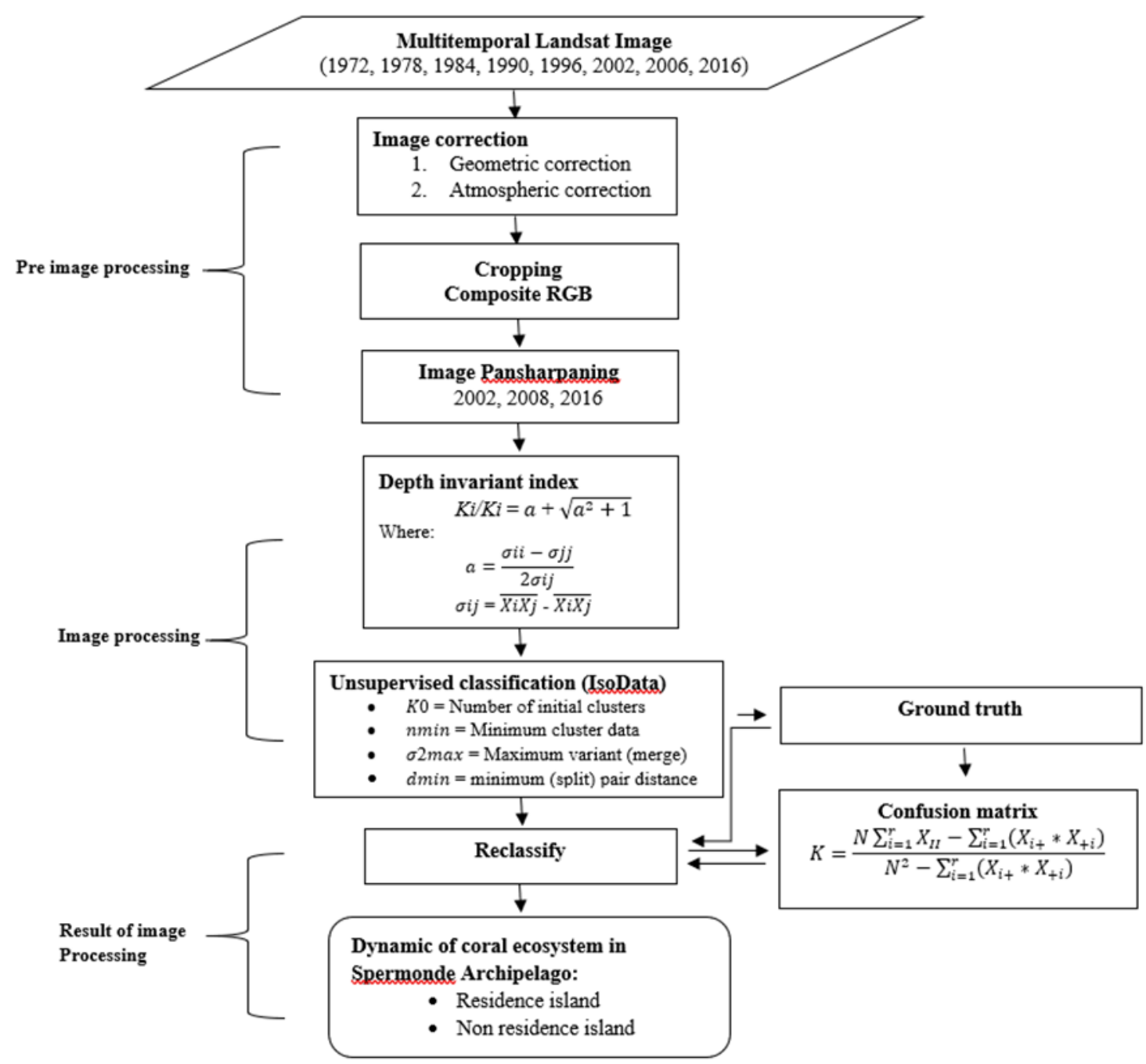

Figure 2. Flowchart of image processing in Spermonde Archipelago

\subsection{Principal Component Analysis (PCA)}

Analysis of Characteristics and spatial-temporal changes in the components of coral ecosystems using Principal Component Analysis (PCA) [25]. PCA analysis was carried out using data on the percentage area of 6 ecosystem components of Dead Coral with Algae (DCA), Live Coral (LC), Rubber (RB), Seagrass (SG), Mix Bottom (MB) and sand (SD) of the total land area of 17 islands that have recorded data from 1972 to 2016. PCA analysis was carried out for three years, namely 1972, 2008 , and 2016, to see changes in characteristics based on the observing variables of the observation group and using six variables. 


\subsection{Regression Analysis}

Analysis of the relationship between the number of population with a reduction in the area of live coral (LC), increase in the area of dead coral (DCA) and increase in the area of rubble (RB) then used multiple linear regression analysis (Multiple Regression Analysis) There are three variables $Y$ namely the reduction in the area of live coral (Y), an increase in the area of dead coral (Y2) and an increase in the area of rubble (Y3) and two variables $\mathrm{X}$ namely the initial area of live coral (X1) and the population $(\mathrm{X} 2)$. The use of the initial land area variable $(\mathrm{X} 1)$ in the three responses observed was since these three variables are theoretically very influenced by the area of living coral land that exists besides the population.

Another reason is to compare the influence of the area of living coral with the population on the three responses observed. This analysis uses data on changes in the area of live coral, dead coral, and rubble from 2008 to 2016 following available population data and records of the extent of the constituent components of coral ecosystems. Because not all islands have population data, so 11 villages are used: Mattiro Sompe, Mattiro Uleng, Mattiro Bulu, Mattiro Labangeng, Mattiro Kanja, Mattiro Baji, Mattiro Bone, Mattiro Deceng, Mattiro Dolangeng, Mattiro Walie, and Mattiro Langi.

The linear model of the multiple linear regression analysis [26] is:

$$
\mathrm{Y}=\alpha+\beta 1 \mathrm{X} 1+\beta 2 \mathrm{X} 2
$$

Where:

$\mathrm{Y}$ : Response, consisting of 3 namely Reduction in the area of live coral $(\mathrm{Y})$, increase in the area of dead coral (Y2) and the addition of rubble area (Y3)

$\alpha:$ Intercept

$\beta 1$ and $\beta 2$ : Slope (Regression coefficient) at X1 and X2

$\mathrm{X} 1$ and $\mathrm{X} 2$ : Variable Area of initial live coral (X1) and total population (X2)

\section{Results and Discussion}

\subsection{Coastal ecosystem degradation}

The level of damage to coral reefs in Indonesia is very alarming. The causes of damage to the coral reef itself can be grouped into two parts, namely, damage caused by human activities (anthropogenic causes) and damage caused by natural processes [27]. Coral damage which is caused by human activities includes excessive fish, taking out biota or coral reefs to be prepared, disposing of trash in the sea, as well as activities that do not care about the environment. Damage caused by natural processes is divided into two parts, namely, damage caused by physical processes and damage caused by biological processes [28].

Changes in the condition of coral reefs are proved quantitatively through changes in the area of live coral, dead coral, rubble, seagrass, and a mix of live coral, dead coral, rubble and sand. There was a decrease in the area of live coral occurring on seventeen islands (Figures 3, 4, and 6) categorized as inhabited islands. The decline in live coral continuously from 1972 until 2016 tends to be followed by an increase in dead coral and rubble.

The decline in the area of live coral that occurred from 1972 to 2016 ranged from $63-86 \%$. The small islands with the highest decreases were Salebo, Kulambing, and Saugi. Two of these islands are located near the mainland of the South Sulawesi Province to the north. In addition to destructive fishing, the influence of sedimentation from mainland river basins is one of the causes of the drastically decreasing area of live coral. Besides, Sarappo and Pajenekang islands have a vast expanse of living coral compared to other smaller islands.

The analysis shows that between population islands and no population islands have a similar trend; from year to year, there is a continual reduction in the area of living coral. Decreased areas of live coral ranged from $74-80.91 \%$. 

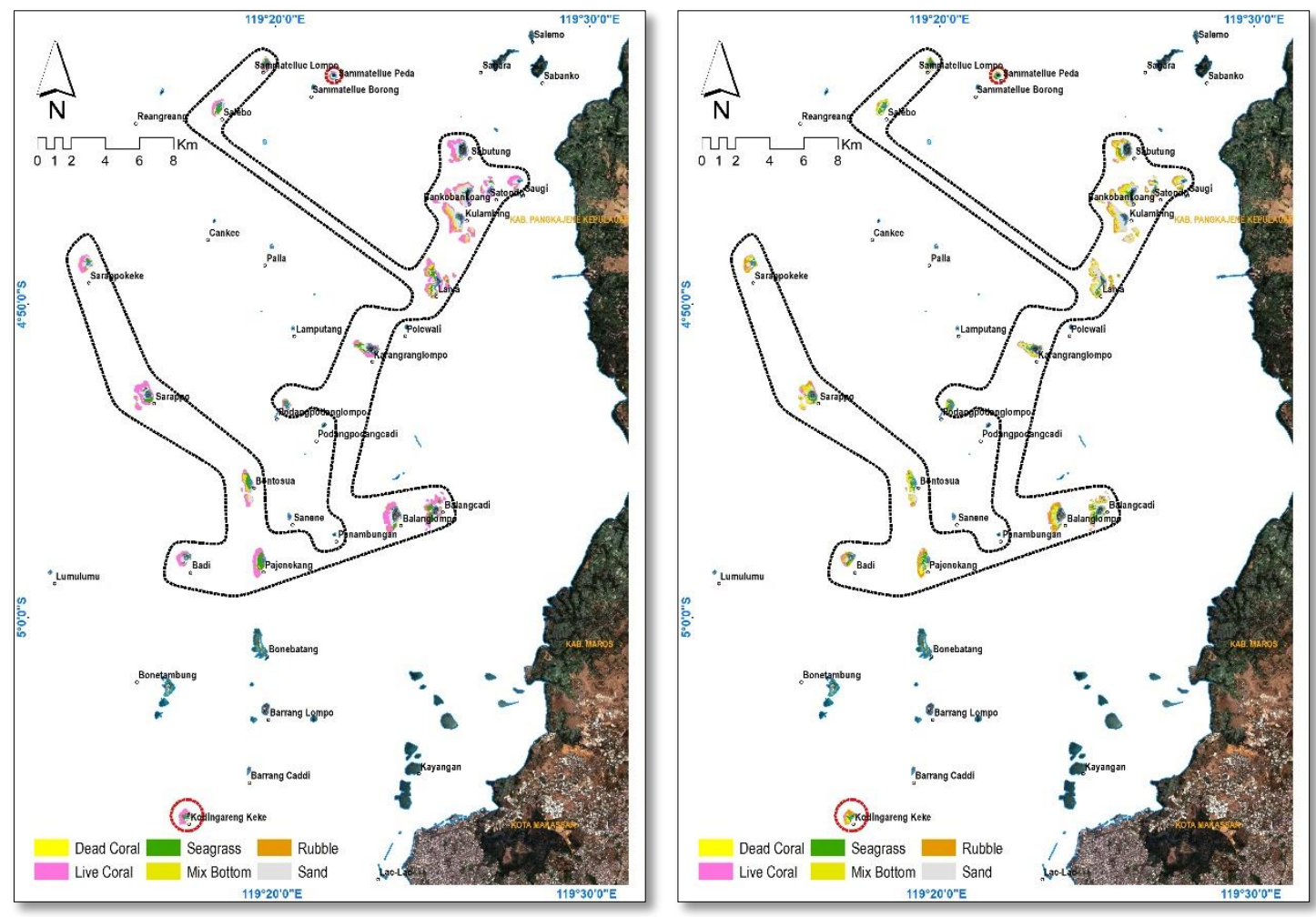

Figure 3. Classification of coral reef distribution and condition in Spermonde island using Landsat imagery data acquisition in 2016. The red line is the border of two non-populated islands, and the violet line is the border of seventeen population islands.

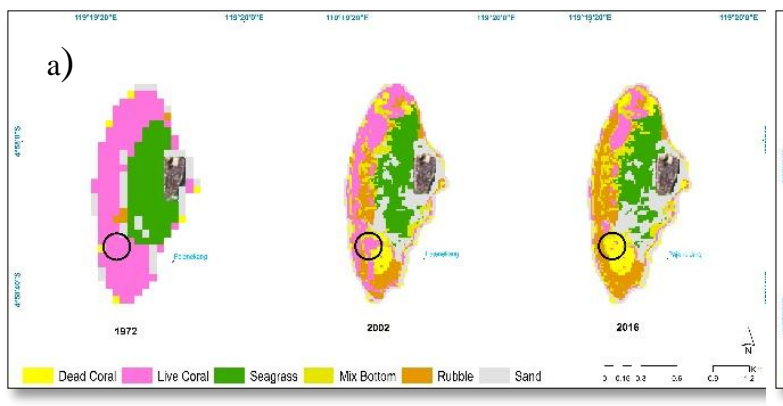

b)
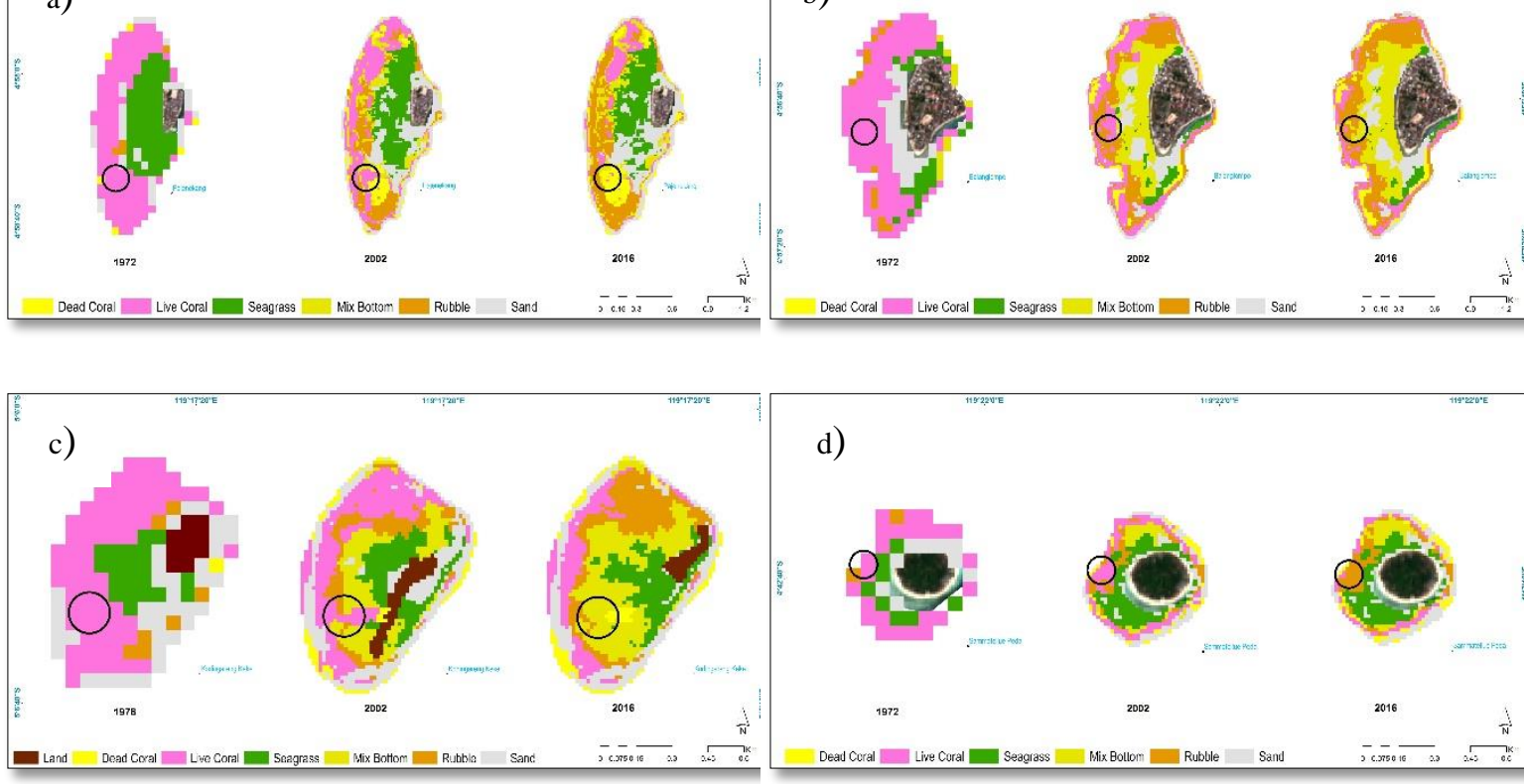

d)

Figure 4. Map of the Landsat satellite image acquisition in 1972, 2002, and 2016 on two population islands (a. Pajenekang, b. Ballang Lompo) and two no population islands (c. Kodingareng Keke, d. Samatellu Peda). The black circle is an area that changes in the substrate of the shallow water from life into rubble and dead coral.

A decrease in the area of live coral is occurring, but on the other hand, there is an increase in dead and rubble corals. In other words, some damaging activities and environmental influences can 
be the cause of living corals to become dead corals, and most of them also become fragments of corals that eventually die.

The number of populations on several small islands is recorded differently by several activities in this area. However, the data used is recording by the Central Statistics Agency of Pangkep Regency [18], which calculates the population of small islands based on the level of the village. Each village can consist of one or several small islands that are close to each other.

Another approach used to strengthen the population figures is counting the number of houses. The number of houses is calculated using UAV photo shoots. As shown in Figure 5, the islands of Ballang Lompo and Pajenekang are the two islands that have the most and densest houses among the seventeen islands studied. The number of houses in Ballang Lompo Island is 695, and Pajenekang Island is 238 houses. Generally, one house is inhabited by around 4-6 people. So that the number of houses based on calculations from UAV photographs shows a significant amount with the population.
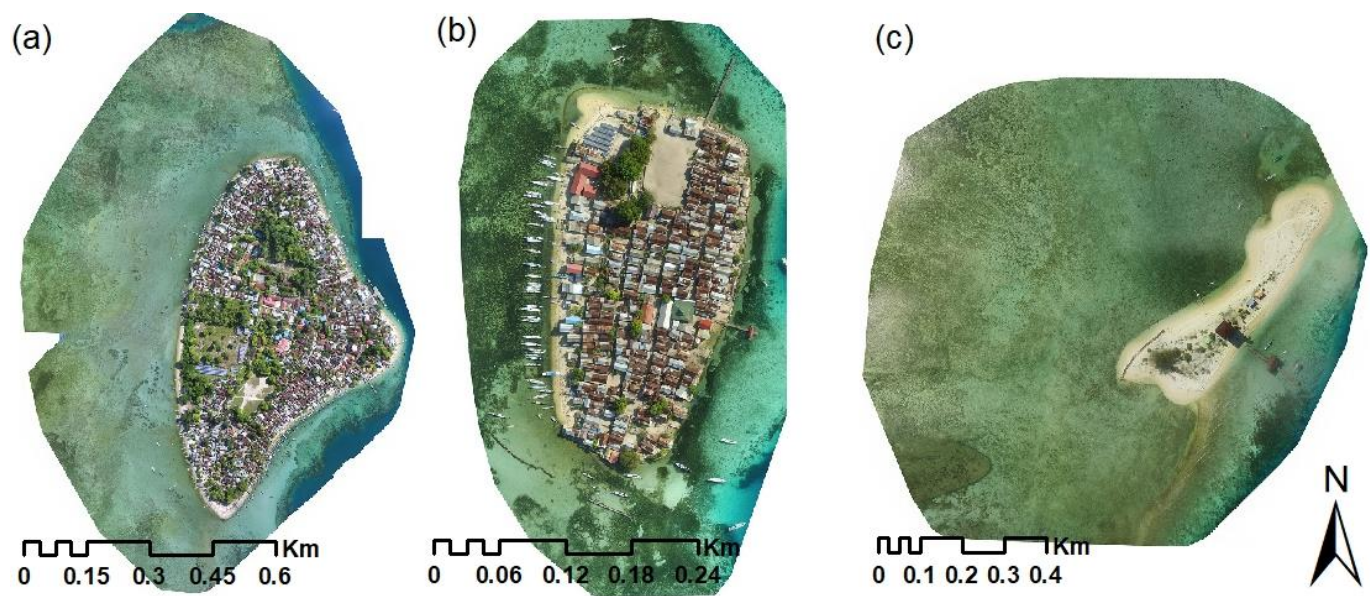

Figure 5. Photograph of the Unmanned Aerial Vehicle (UAV) using Phantom 4 acquisition 2018 on two populated islands, which are Ballang Lompo (left) and Pajenekang (middle), and Kodingareng Keke island (right) as not populated islands.

The socioeconomic condition of the people on this small island has a semi-permanent house. The entire population has not enjoyed electricity from the State Electricity Company (PLN), but relies on the island's self-generated power sources using diesel engines and only operates at 06:00 pm and electricity goes out at 06:00 am. The primary lighting sources generally use generators and solar power. Also, the majority of the population in the study location still uses a type of latrine that immediately dumps its waste into the sea.

Ground check results show that the precision value from Landsat satellite image analysis is appropriate. The accuracy of Landsat satellite imagery using confusion matrix calculations of seventeen small islands is $65-82.61 \%$.

\subsection{Characteristics of Components for the Development of Coral Ecosystems in the Spermonde Islands}

The characteristics of the constituent components of coral ecosystems in the Spermode Islands are explained based on the spatial-temporal changes that occur in the elements of the ecosystem, namely live coral (LC), dead coral overgrown with algae (DCA), Mix Button (MB), Rubble (RB), sand (SD) and seagrass (SG). The analysis used is principal component analysis or PCA (Principal Component Analysis) using data on the percentages of the six ecosystem components on 17 islands that analyzed in three different years (1972, 2008 and 2016). The results of the PCA analysis showed that the majority $(>75 \%$ ) of variance was explained in the three axes or principal components of the three years of data analyzed with the eigenvalue, as presented in Table 1. 

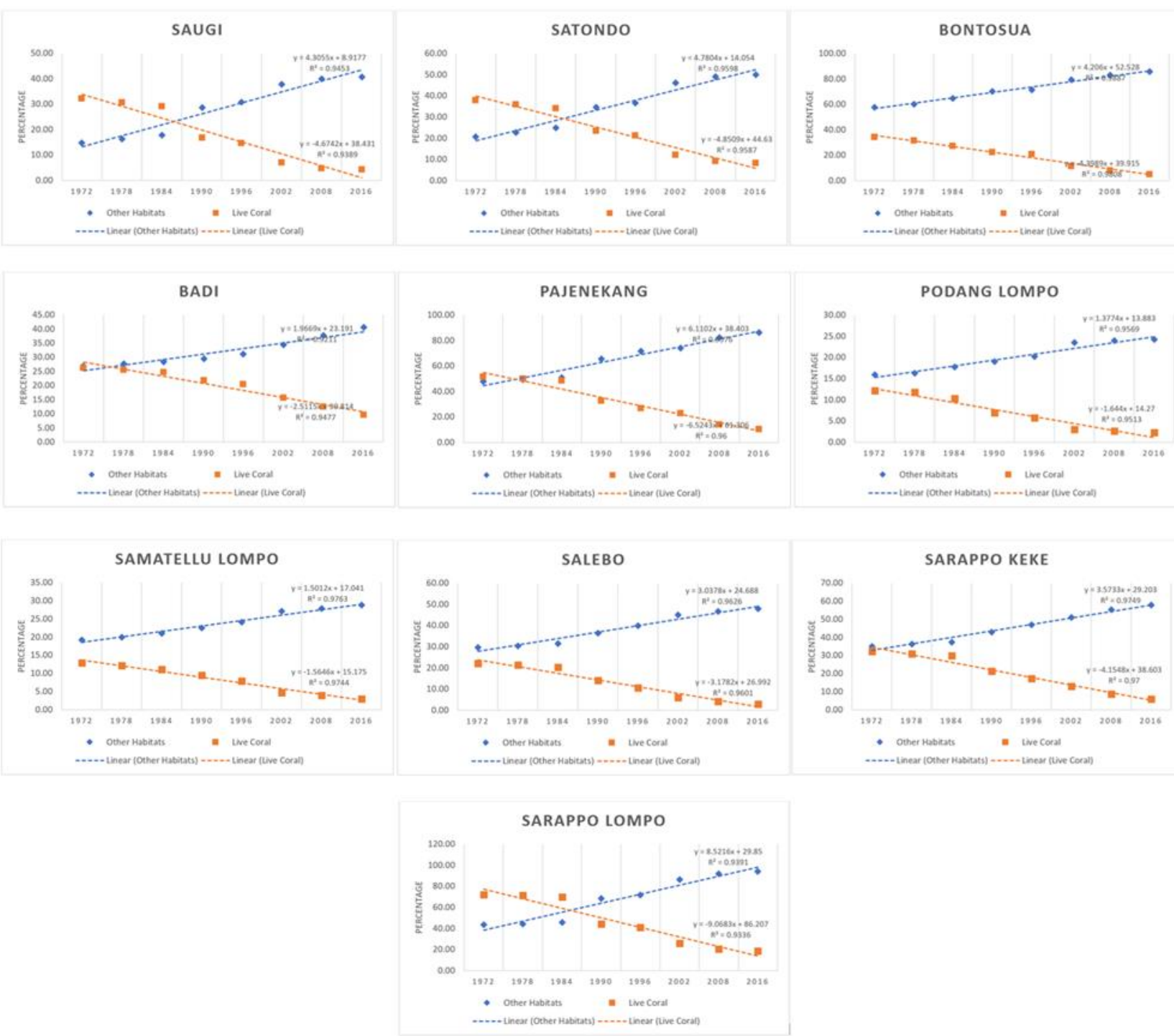

Figure 6. Dynamic graphs of live coral changes in the time range of 1972, 1978, 1984, 1990, 1996, 2002, 2008, and 2016 in small inhabited islands in the Spermonde Archipelago.
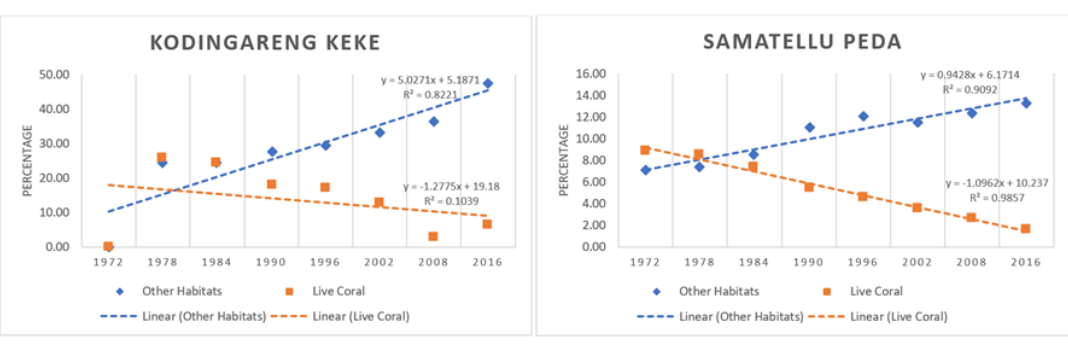

Figure 7. Graph of dynamics of live coral in 1972, 1978, 1984, 1990, 1996, 2002, 2008, and 2016 in small islands with no population of the Spermonde Islands: a). Kondingareng, Keke, and b). Samatellu Peda

The results of the PCA analysis showed very significant changes, especially from 1972 to 2008 , while from 2008 to 2016, the results of the investigation did not show any significant changes. In 1972 the contribution of dead coral components overgrown with algae (DCA) and seagrass (SG) was a substantial contributor to the formation of axis one while in 2008, the role of Mix Buttom (MB) and Seagrass (SG) and in 2016 was higher. The purpose of Mix Buttom (MB), Seagrass (SG), and Live Coral (LC). Differences in the identifier variables and aggregate observations (17 islands) during 1972, 
2008 and 2016 showed a fundamental difference, especially between 1972 and 2008 and 2016, as shown in the biplot in Figure 8.

Table 1. Values of root features and cumulative variance explained in three main components (F1, F2, and F3) according to PCA results in 1972, 2008 and 2016.

\begin{tabular}{ccccc}
\hline Year & Parameter & F1 & F2 & F3 \\
\hline \multirow{2}{*}{1972} & Eigenvalue & 1.9174 & 1.7299 & 1.3938 \\
& Variability (\%) & 31.9561 & 28.8322 & 23.2298 \\
& Cumulative \% & 31.9561 & 60.7883 & 84.0181 \\
\hline \multirow{2}{*}{2008} & Eigenvalue & 1.9980 & 1.6919 & 0.8862 \\
& Variability (\%) & 33.3005 & 28.1983 & 14.7692 \\
& Cumulative \% & 33.3005 & 61.4987 & 76.2679 \\
\hline \multirow{2}{*}{2016} & Eigenvalue & 2.0546 & 1.7356 & 0.9254 \\
& Variability (\%) & 34.2442 & 28.9274 & 15.4232 \\
& Cumulative \% & 34.2442 & 63.1715 & 78.5947 \\
\hline
\end{tabular}

Biplot in the picture $x$ above shows that very clearly visible striking the difference between images A with B and C. Components (DCA) and SG contributed significantly and positively correlated with positive axis one while in 2008 and 2016 the contribution of this variable was minimal and negatively correlated with the one stab. High DCA and SG variables characterized locations in Pulai Sarappo Lompo (SLL), Podang-Lompo (PPL), Salebo (Sal), Samatellu Lompo (STL) and Pajenekang (Paj) in 1972.

Based on the aggregate patterns of observations and variables in 2008 and 2016 (Figures B and C), it is seen that a high percentage of live coral (LC) is a characteristic of the Badi (Bad) island and consistent in 2016. Similarly, Saugi Island (Sa) and Sabutung (Sat) characterized by a high percentage of Mix Buttom (MB), where this value was zero in 1972 in both locations. The pattern of aggregate observations and variables is relatively unchanged from 2008 to 2016. Based on the results of the PCA analysis, it is most likely to have something to do with the conservation and protection of coral reef ecosystems that have been intensively carried out in recent years so that the impact of damage is no longer as large occur when compared to the period between 1972 and 2008. During this period (20082016), awareness of Indonesian communities increased as the government published some regulations and promotion to conserve marine and coastal ecosystems. The Ministry of Marine and Fisheries of Indonesia has enforced some regulations to reduce the illegal and unreported marine exploitation [29].

\subsection{Relationship Between Population Numbers and Reduction in Living Coral Areas}

The results of regression analysis between Reducing Live Coral Area (Y) with Early Living Coral Area (X1) and Population Number (X2) show that the reduction in living coral area is significantly correlated $(\mathrm{P}<0.01)$ with initial living coral area and population in 11 villages in Spermonde Islands in the period 2008 to 2016 (Appendix). The partial correlation test shows that the reduction in the area of living coral significantly correlates positively with the initial area of living coral (in 2008) and the average population (from 2008 to 2016) with a partial correlation value (R) of 0.904 and 0.770 , respectively.

The relationship between the reduction in the area of live coral $(\mathrm{Y})$ with the initial area of living coral (X1) and total population (X2) follows the equation: $\mathrm{Y}=-3.0349+0.2945 \mathrm{X} 1+0.0012 \mathrm{X} 2$ with the coefficient of determination $(\mathrm{R} 2)=0.856$. The results of this regression mean that the magnitude of the diversity of the reduction in the area of live coral is affected or can be explained by the magnitude of diversity simultaneously, the initial area of live coral, and the total population of $85.6 \%$. Most $(85.6 \%)$ changes in the area of living coral are influenced by two variables $\mathrm{X}$, namely the initial area of living coral and the total population. The remaining $14.5 \%$ is influenced by other factors not analyzed. 

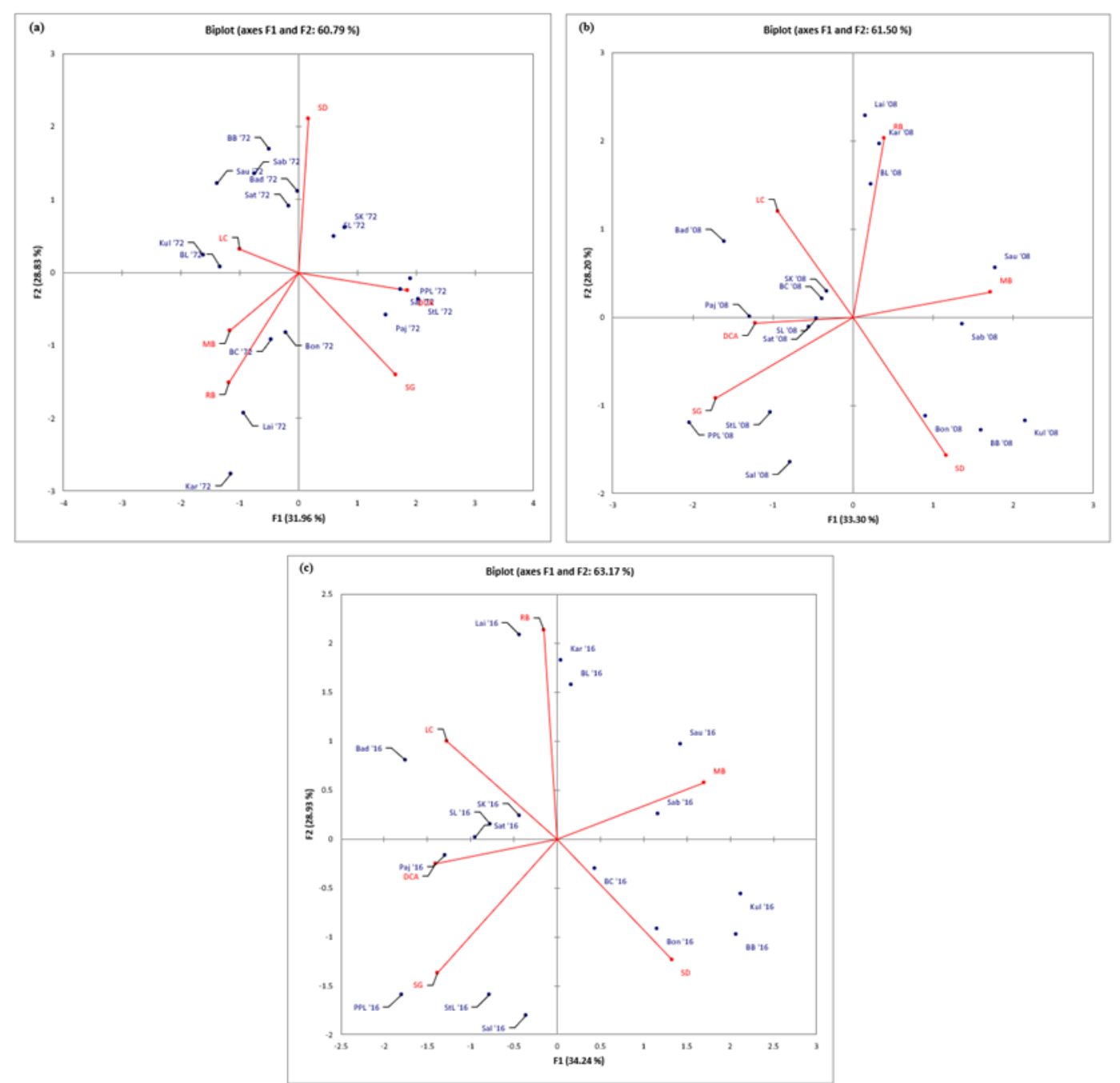

Figure 8. Observation plots and variables on axes 1 and 2 based on PCA results in 1972 (top-left), 2008 (top-right), and 2016 (bottom panel).

Referring to the value of the regression coefficient, it can be said that the reduction in the area of live coral will increase along with the increase in the initial area of living coral and the average number of inhabitants, in contrast, decreases with the decrease in the initial area of living coral and the total population. The reduction in the area of living coral will increase by $0.2945 \mathrm{Ha}$ per increase in the initial area of living coral by $1 \mathrm{Ha}$, assuming that the population is constant. In other words, the reduction in the area of live coral increases by $0.12 \mathrm{Ha}$ for each increase in the population of 100 people at the initial value of a particular area of live coral in the span of observation.

The results of this analysis explain that there is a tendency for the magnitude of the reduction in the area of living coral to be higher on smaller islands or village whose coral life is more extensive when compared to smaller islands whose coral life is narrower - assuming that when the population approaches a constant and the tendency of the area of living corals to decrease, each reduction of 1 Ha of living corals, the decline for 8 years from 2008 to 2016 is 0.2945 Ha or around 0.037 Ha per year and if present, there will be a decrease of $3.7 \%$ per year.

The results of the analysis show a higher reduction in the area of live coral on a broader area of living coral, it is associated with the form of community activities in damaging corals such as the use of bombs, chemical, and mining, so in fact it can be explained that indeed these activities tend to be more intensive in areas whose coral life is still extensive because in areas with broader corals still 
inhabited by many species and abundance of fish that are relatively higher so that the area is preferred as a fishing ground.

The effect of the population shows a positive correlation with the reduction in the area of live coral, although it is significant, its effect is relatively lower when compared to the influence of the area of living coral. It can be explained from the fact that in the practice of coral destruction on an island, it is usually not only caused or carried out by residents who live on the island but also carried out by other residents of different islands.

Although on an island the increase in population is not so significant or even decreases from year to year but on the island the area of coral reefs is still quite large, the reduction in the area of living coral on the island will still be higher because residents from other islands contribute to coral destruction. On the other hand, a small island with a high increase in population from year to year, but the remaining living coral area is small, then the reduction will be lower. Seeing this fact and adjusting the results of the analysis, it can be assumed that during the period 2008-2016, the behavior of the use of corals, especially mining, for the making of house foundations.

There was a tendency for the selection of areas to be mined based on the consideration of the remaining living coral area where mining tendencies were carried out in the regions the vast remaining coral life is still high. Therefore, the effect of the number of populations, although significant, is not as large as the influence of the initial area of living coral in influencing the reduction of the area of living coral in an area.

The degradation of coral reefs is not entirely related to population density on a small island, so the influence of local population pressure on a small island does not strongly affect the geographical scale. Many locations are used as centers of activity for residents and are exposed to various potential local pressures, but the impact is weak or has antagonistic interactions with global stressors [30].

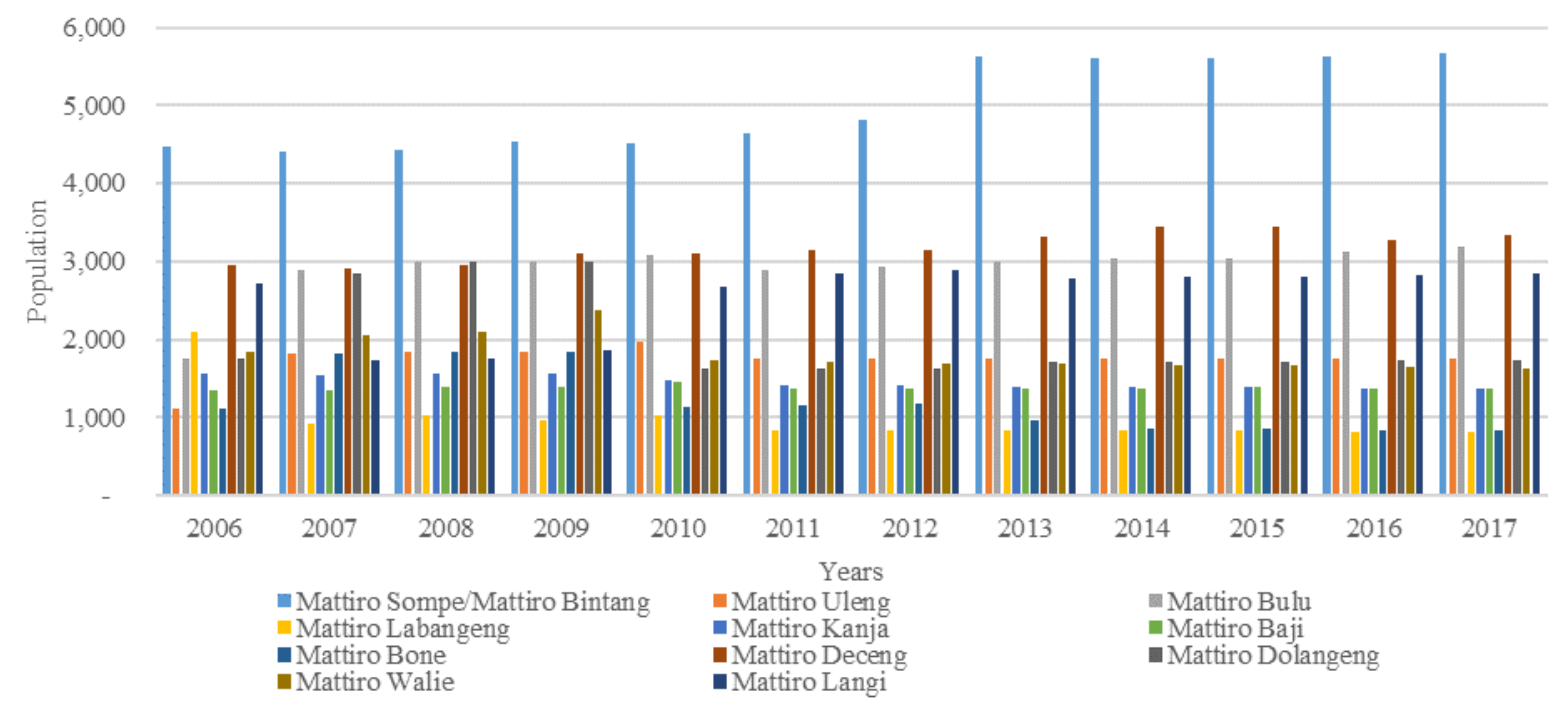

Figure 9. Diagram of population growth dynamics in 2006-2017 of 11 urban villages consist of 17 small islands of Spermonde Archipelago.

\subsection{Population and Extent of Dead Reefs and Rubble}

The consequence of reducing live coral is an increase in the number of dead corals and rubble. The two components of coral ecosystems are theoretically still related to living corals and population. To see this effect, multiple linear regression analysis is used between the Addition of Dead Reef Area (Y2) to the Initial Living Reef Area (X1) and Population Amount (X2).

The results show that the increase in the area of dead coral significantly correlates $(P<0.01)$ with the initial area of live coral and population (Appendix). The partial correlation test shows that the reduction in the area of live coral is a significantly positive partial correlation with the initial area of 
living coral and the average number of residents with a partial correlation value (R) of 0.893 and 0.706 , respectively.

The relationship between the addition of dead coral area (Y2) with the initial area of live coral (X1) and population $(\mathrm{X} 2)$ follows the equation $\mathrm{Y} 2=-0.1274+0.0421 \mathrm{X} 1+0.0001 \mathrm{X} 2$ the coefficient of determination $(\mathrm{R} 2)=0.811$. This result means that the magnitude of the diversity of extending dead coral area is influenced or can be explained by the simultaneous magnitude of the diversity of the initial live coral area and a population of $81.1 \%$. This magnitude means that the initial area of live coral influences $81.1 \%$ increase in the area of dead coral and the total population, and the remaining $18.9 \%$ is influenced by other factors not analyzed.

Referring to the sign of the value of the regression coefficient, it can be said that the increase in the area of dead coral will increase with the increase in the initial area of live coral and the average population. The increase in the area of dead coral will increase by $0.0421 \mathrm{Ha}$ for every initial increase in area of living coral by one assumption that the population is constant or increases by $0.01 \mathrm{Ha}$ for an increase in the population of 100 people at the initial value of a specific area of living coral within the observing time span.

The effect of the initial living area and population on the increase in the area of dead coral appears to have a pattern similar to the decrease in the area of live coral. The difference is seen from the coefficient value at $\mathrm{X} 1$, wherein the reduction of live coral area $=0.2945$ and in the addition of dead coral area by 0.0421 . It means that not all the decrease in the area of living coral is changed or converted to dead coral, but there are rubble, sand, and seagrass. If the ratio of the values of these two coefficients is 0.0421: $0.2945=14.30 \%$ compared to the total reduction in the area of live coral and the addition of dead coral area from 11 villages in 2008-2016, namely 54.77 Ha: $9.27=17.11 \%$, then there is a difference where the difference is caused by variations in the number of residents in each village. In the results of the analysis also showed that the coefficient value of the effect of the number of population on the addition of dead coral area by 0.01 Ha for each increase of 100 inhabitants the value is lower than the addition of dead coral area by 0.037 Ha every increase of 100 inhabitants.

The conclusion that can be drawn from the comparison of the two regression analyses is that although the reduction in the area of live coral and the increase in the area of dead coral are both influenced by the initial amount of living coral and the population, the different magnitude of the regression coefficient indicates that not all the reduction in the living coral area becomes dead coral, but there are other factions namely rubble, sand and seagrass. To evaluate the magnitude of changes to different fractions, specifically those that become rubble, a regression used to analyze between the addition of the rubble area and the initial area of live coral and the population. To see this effect, multiple linear regression analysis is used between the addition of Rubble Area (Y3) to the Initial Living Reef Area (X1) and Population Amount (X2). The results of the analysis (Appendix) show that the addition of the rubble area is significantly correlated $(\mathrm{P}<0.01)$ with the initial area of live coral and population. The partial correlation test shows that the reduction in the area of live coral is a significantly positive partial correlation with the initial area of living coral and the average number of residents with a partial correlation value $(\mathrm{R})$ of 0.884 and 0.783 , respectively.

The relationship between the addition of rubble area $(\mathrm{Y} 3)$ with initial area of living coral $(\mathrm{X} 1)$ and population $(\mathrm{X} 2)$ follows the equation: $\mathrm{Y} 3=-0.9536+0.1024 \mathrm{X} 1+0.0005 \mathrm{X} 2$ with the coefficient of determination $(R 2)=0.836$. These results mean that the magnitude of the diversity of the addition of rubble area is influenced or can be explained by the magnitude of diversity simultaneously in the area of initial live coral and the total population of $83.6 \%$. This magnitude means that the initial area of living coral influences $81.1 \%$ increase in rubble area and the total population, and the remaining $16.4 \%$ is influenced by other factors not analyzed. The addition of the rubble area will increase with the growing area of the initial live coral and the average population. The addition of rubble area will increase by $0.1024 \mathrm{Ha}$ each increase in the initial area of living coral by $1 \mathrm{Ha}$ assuming that the population is constant or increases by $0.05 \mathrm{Ha}$ for every increase in population by 100 people at the initial value of a certain live coral area within the observing period.

If the $\mathrm{X} 1$ coefficient value of 0.1024 in the regression of the addition of rubble area is compared with 0.0421 in the regression of the addition of dead corals, it can be stated that the conversion of live 
coral to rubble is higher than that of dead coral. When compared with the coefficient X1 in the regression of living coral area reduction of 0.2945 , the magnitude of reduction in the area of living coral converted to rubble according to the estimated regression equation reaches $34.77 \%$. This value is higher than that which is converted to dead coral by $14.30 \%$.

The greater of live coral reduction to rubble compared to dead coral cover with algae can be caused by various factors such as the location of exposed sediments and high energy [31]. Also, the formation of rubble can be caused by various anthropogenic activities such as the use of bombs (blast fishing), anchoring damage, ship grounding as observed at depths of less than three meters on several islands in the Spermonde Islands (Samalona, Barranglompo, and Kapoposang). At a depth of 10 meters (reef slope), the effect of this factor is no longer found [32].

\section{Conclusions}

The results of the analysis show a higher reduction in the area of life coral on a broader area of living coral, it is associated with the form of community activities in damaging corals such as the use of bombs, chemical, and mining, so in fact it can be explained that indeed these activities tend to be more intensive in areas whose coral life is still extensive because in areas with broader corals still inhabited by many species and abundance of fish that are relatively higher so that the area is preferred as a fishing ground. The effect of the population shows a positive correlation with the reduction in the area of live coral, although it is significant, its effect is relatively lower when compared to the influence of the area of living coral, which can be explained from the fact that in the practice of coral destruction on an island it is usually not only caused or carried out by residents who live on the island but also carried out by other residents of different islands.

Acknowledgments: This research was supported by the Ministry of Research Technology and Higher Education of the Republic of Indonesia for the generous support in providing research funds. Thanks to Environmental Systems Research Institute (ESRI) Indonesia for software supporting. We thank the Ocean Remote Sensing Project of Subcommission of Western Pacific Intergovernmental Oceanographic Commission/UNESCO supported by Japan Fund in Trust provided by the Ministry of Education, Culture, Sports, Science and Technology, Japan.

\section{References}

1. Goodman, J.A.; Purkis, S.J.; Phinn, S.R. Coral Reef Remote Sensing: A Guide for Mapping, Monitoring and Management; Springer Netherlands, 2013; ISBN 978-90-481-9291-5.

2. Hedley, J.D.; Roelfsema, C.M.; Chollett, I.; Harborne, A.R.; Heron, S.F.; Weeks, S.; Skirving, W.J.; Strong, A.E.; Eakin, C.M.; Christensen, T.R.L.; et al. Remote Sensing of Coral Reefs for Monitoring and Management: A Review. Remote Sens. 2016, 8, 118.

3. Eakin, C.M.; Nim, C.; Brainard, R.; Aubrecht, C.; Elvidge, C.; Gledhill, D.; Muller-Karger, F.; Mumby, P.; Skirving, W.; Strong, A.; et al. Monitoring Coral Reefs from Space. Oceanography 2010, 23, 118-133.

4. El-Askary, H.; El-Mawla, S.; Li, J.; El-Hattab, M.; El Raey, M. Change detection of coral reef habitat using Landsat5 TM, Landsat 7 ETM+ and Landsat 8 OLI data in the Red Sea Hurghada, Egypt. Int. J. Remote Sens. 2014, 35, $2327-2346$.

5. Nurdin, N.; Komatsu, T.; Agus; Akbar AS, M.; Djalil, A.R.; Amri, K. Multisensor and multitemporal data from Landsat images to detect damage to coral reefs, small islands in the Spermonde archipelago, Indonesia. Ocean Sci. J. 2015, 50, 317-325.

6. Chen, C.-F.; Lau, K.; Chang, N.-B.; thanh son, N.; Phuoc Hoang Son, T.; Chiang, S.-H. Multi-temporal change detection of seagrass beds using integrated Landsat TM/ETM+/OLI imageries in Cam Ranh Bay, Vietnam. Ecol. Inform. 2016, 35 . 
7. Haya, L.O.M.Y.; Fujii, M. Mapping the change of coral reefs using remote sensing and in situ measurements: a case study in Pangkajene and Kepulauan Regency, Spermonde Archipelago, Indonesia. J. Oceanogr. 2017, 1-23.

8. Greene, A.L. Applications of Side Scan and Parametric Echosounders for Mapping Shallow Seagrass Habitats and Their Associated Organic Carbon. Masters Thesis 2017, 17.

9. Silva, G.C.M. da; Souza, F.E.S. de; Marinho-Soriano, E. Application of ALOS AVNIR-2 for the detection of seaweed and seagrass beds on the northeast of Brazil. Int. J. Remote Sens. 2017, 38, 662-678.

10. Geevarghese, G.A.; Akhil, B.; Magesh, G.; Krishnan, P.; Purvaja, R.; Ramesh, R. A comprehensive geospatial assessment of seagrass distribution in India. Ocean Coast. Manag. 2018, 159, 16-25.

11. Global Maritime Boundaries Database Available online: http://www.globalgisdata.com/10974.html (accessed on Nov 10, 2019).

12. DeCarlo, T.M.; Cohen, A.L.; Wong, G.T.; Davis, K.A.; Lohmann, P.; Soong, K. Mass coral mortality under local amplification of $2{ }^{\circ} \mathrm{C}$ ocean warming. Sci. Rep. 2017, 7, 44586-44586.

13. Burke, L. Reefs at Risk in Southeast Asia Available online: https://www.wri.org/publication/reefs-risk-southeastasia (accessed on Nov 10, 2019).

14. Ampou, E.E.; Ouillon, S.; Iovan, C.; Andréfouët, S. Change detection of Bunaken Island coral reefs using 15years of very high resolution satellite images: A kaleidoscope of habitat trajectories. Mar. Pollut. Bull. 2018, 131, 83-95.

15. Lasagna, R.; Gnone, G.; Taruffi, M.; Morri, C.; Bianchi, C.; Parravicini, V.; Lavorano, S. A new synthetic index to evaluate reef coral condition. Ecol. Indic. 2014, 40, 1-9.

16. Nurdin, N. Informasi Geospasial Gugusan Pulau Kecil Kepulauan Spermonde (The Geospatial Information of Small Islands in Spermonde Archipelago; Andi publisher, In Press;

17. Phinn, S.R.; Roelfsema, C.M.; Mumby, P.J. Multi-scale, object-based image analysis for mapping geomorphic and ecological zones on coral reefs. Int. J. Remote Sens. 2012, 33, 3768-3797.

18. BPS, C.S.A. Pangkep District, South Sulawesi;

19. Lyzenga, D.R. Passive remote sensing techniques for mapping water depth and bottom features. Appl. Opt. 1978, 17, 379-383.

20. Green, E.; Mumby, P.; Edwards, A.; Clark, C. Remote Sensing Handbook for Tropical Coastal Management; 2000; ISBN 978-92-3-103736-8.

21. Stumpf, R.; Culver, M.E.; Tester, P.; Tomlinson, M.; Kirkpatrick, G.; Pederson, B.A.; Truby, E.; Ransibrahmanakul, V.; Soracco, M. Monitoring Karenia Brevis Blooms in the Gulf of Mexico Using Satellite Ocean Color Imagery and Other Data. Harmful Algae 2003, 2, 147-160.

22. Siregar, V. The Bottom Substrate Shallow Water Mapping Using the Qick Bird Satellte Imagery. J. Ilmu Dan Teknol. Kelaut. Trop. 2010, 2.

23. Wang, H.; Zhao, Y.; Pu, R.; Zhang, Z. Mapping Robinia Pseudoacacia Forest Health Conditions by Using Combined Spectral, Spatial, and Textural Information Extracted from IKONOS Imagery and Random Forest Classifier. Remote Sens. 2015, 7, 9020-9044.

24. Congalton, R.G.; Green, K. Assessing the Accuracy of Remotely Sensed Data: Principles and Practices, Third Edition Available online: https://www.crcpress.com/Assessing-the-Accuracy-of-Remotely-Sensed-Data-Principles-andPractices/Congalton-Green/p/book/9781498776660 (accessed on Nov 10, 2019).

25. Afifi, A.A.; Clark, V. Computer-aided multivariate analysis; 1st CRC Press reprint.; Boca Raton Chapman \& Hall/CRC, 1999; ISBN 978-0-412-73060-3.

26. Kleinbaum, D.G.; Kupper, L.L.; Nizam, A.; Muller, K.E. Applied Regression Analysis and Other Multivariable Methods; 4 edition.; Duxbury Press: Australia ; Belmont, CA, 2007; ISBN 978-0-495-38496-0.

27. Dahuri, R. Pengelolaan Ruang Wilayah Pesisir dan Lautan Seiring Dengan Pelaksanaan Otonomi Daerah. $2001,33$.

28. Fagerstrom, J.A. The evolution of reef communities; Wiley: New York, N.Y, 1987; ISBN 978-0-471-81528-0. 
29. Susanto, H.; Sunardi subari, S.; tokeshi, mutsunori Management of Coral Reef Ecosystems in Indonesia: Past, Present and the Future. Coast. Ecosyst. 2188-2037 2015, 2, 21-41.

30. Bruno, J.F.; Valdivia, A. Coral reef degradation is not correlated with local human population density. Sci. Rep. 2016, 6, 29778.

31. Shannon, A.M.; Power, H.E.; Webster, J.M.; Vila-Concejo, A. Evolution of Coral Rubble Deposits on a Reef Platform as Detected by Remote Sensing. Remote Sens. 2013, 5, 1-18.

32. Edinger, E.N.; Jompa, J.; Limmon, G.V.; Widjatmoko, W.; Risk, M.J. Reef degradation and coral biodiversity in indonesia: Effects of land-based pollution, destructive fishing practices and changes over time. Mar. Pollut. Bull. 1998, 36, 617-630. 